\title{
Consequential Effects of Budget Deficit on Economic Growth: Empirical Evidence from Ghana
}

\author{
Samuel Antwi ${ }^{1,2}$, Xicang Zhao ${ }^{1} \&$ Ebenezer Fiifi Emire Atta Mills ${ }^{3}$ \\ ${ }^{1}$ School of Finance and Economics, Jiangsu University, Jiangsu, China \\ ${ }^{2}$ Koforidua Polytechnic, P.O.Box KF981, Koforidua, Ghana \\ ${ }^{3}$ School of Business Administration, Jiangsu University, Jiangsu, China \\ Correspondence: Samuel Antwi, School of Finance and Economics, Jiangsu University, 301 Xuefu Road, \\ Zhenjiang, Jiangsu, China. E-mail:samyantwi@yahoo.com
}

Received: December 28, 2012

Accepted: January 24, $2013 \quad$ Online Published: February 22, 2013

doi:10.5539/ijef.v5n3p90

URL: http://dx.doi.org/10.5539/ijef.v5n3p90

\begin{abstract}
The study evaluates budget deficit sustainability of Ghana between 1960 and 2010 using the present value budget constraint approach. By applying annual time series data, the ADF and PP tests for unit root rejected the null hypothesis at 1 percent significance level after first difference. Hence, both government expenditure and revenue of Ghana are stationary and integrated of order one. The Granger causality test supported a bi-directional causation such that both expenditure and revenue of Ghana have temporal precedence over each other. This means past and present values of government revenue provide important information to forecast future values of expenditure. The test for cointegration favored the sustainability of budget deficit of Ghana at 10 percent significance level in the strong sense. In this case, government can continue to service its past accumulated deficits without large future correction to the balance of income and expenditure. Again, the study achieved the conventional negative sign of the speed of adjustment to long run equilibrium following shocks to the system at 5 percent significance level.
\end{abstract}

Keywords: Ghana, budget deficit, government revenue, government expenditure, cointegration

\section{Introduction}

Budget deficit arises when the demand for government expenditure far exceeds government revenue that needs to be financed by net lending. For the economy of Ghana, there has been persistent tendency towards budget deficit since independence as a result of ever expanding government expenditure, inadequate revenue generation capacity of government and increasing debt levels [Pomeyie, 2001: 162]. For instance, the deficit-GDP of Ghana increased from 7.8 percent in 2005 to 8.1 percent in 2006 and 9.6 percent in 2007 and 14.5 percent in 2008 [IEA, 2008: 23-29]. As the economy of Ghana grows, policy makers have been concerned with the extent to which the budget deficit is sustainable. For most years, government expenditure has exceeded government revenue in Ghana leading to deficits on the budget. Expenditure has been rising steadily due to increase demand for infrastructure and payment of interest on debt. For instance, total expenditure to GDP increased from 31.62 percent in 2005 to 33.71 percent in 2006 and 35.9 percent in 2007 [Bank of Ghana, 2007: 2]. Yet, it is important that the government of Ghana run some fiscal deficits in order to stimulate economic growth by building up enough capital stock. This would place the economy on its steady state growth path so that debt can be issued to cover the deficits and repaid in the future [Xiomara and Greenidge, 2003: 2-3]. Contrary, the various sources of Ghana's revenue have become highly inadequate due to narrow tax base, high rate of tax evasion and corruption in the revenue collection agencies. This has led to over spending by the government which tends to create deficit on the budget. For instance, total government revenue to GDP increased marginally from 23.87 percent in 2005 to 24.1 percent 2006 but declined to 23.6 percent in 2007 [Bank of Ghana, 2007]. The persistent deficit in Ghana means that the debt level and its servicing will continue to grow without limit unless constrained. This may lead to explosion of the debt-GDP ratio of Ghana due to higher interest payment such that large and costly adjustment must be made in future to correct the budget. In this regard, it is important to examine the problem of study.This study aims at evaluating the sustainability of budget deficit in Ghana between 1960 and 2010. 


\section{Literature Review}

\subsection{Government Budget Deficit}

A deficit policy plays a vital role in assisting countries achieve macroeconomic stability, poverty reduction, income redistribution and sustainable growth. For this reason, most governments use the budget as effective tool in achieving their economic objectives. This means that large and accumulating budget deficit may not necessarily be a bad policy objective if such deficits are effectively utilized to enhance economic growth. It is in line with this that an appropriate operational definition and measure of budget deficit must be clearly stated. Otherwise, the occurrence of large nominal budget deficit may be misleading depending on the operational measure adopted by a particular country.

\subsection{Causes and Determinants of Budget Deficit Growth}

In general, changes in budget deficit is attributed to changes in government spending or tax revenue or both. Government receives revenue in its daily transactions and on capital items in the form of taxes and interests. On the other hand, government pays for daily activities and capital items such as administrative expenses, loans and grants. Thus, budget deficit increases when government spending persistently exceeds its revenue. If expenditure continue to mount up throughout the years whereas revenues especially taxes are poorly collected, it widens the budget deficit position of the country. In this case, the accumulated value of past deficit creates increase debts which must be financed together with the accompanying interest payments.

\subsection{Influence of Revenue-Expenditure Relationship on Budget Deficit}

A method of determining sustainable budget deficit is to check whether government revenue and expenditure are cointegrated. This implies that there may be significant long-term economic relationship between these two variables. There are four hypotheses that examine the influence of revenue and expenditure on budget deficit. The tax-spend hypothesis postulates that raising taxes in an attempt to reduce deficit also causes expenditure to rise. It means that government raises tax revenue ahead of engaging in new expenditure. Contrary, the spend-tax hypothesis predicts that government initially incurs expenditure and then increases tax revenue to finance the deficit.

\subsection{Sustainability of Budget Deficit}

A sound fiscal policy is mandatory for macroeconomic stability and sustainable growth which is a major goal of most emerging market countries such as Ghana. Yet, the size of budget deficit and ways of financing it determine the fiscal constraint of the country in the long term. In this sense, sustainable budget deficit becomes an important factor for which government authorities should pay particular attention [Kustepeli and Onel, 2004: 1-2]. The government's ability to borrow is constrained by the size of its permanent income just like an individual, even if it remains in authority infinitely. This implies that whatever debt it accumulates has to be repaid in the future.

\subsection{Dimensions of Budget Deficit Sustainability}

The controversies regarding conditions of intertemporal budget constraint and the shift to long-term horizon has expanded the way governments and international organizations think about budget deficit sustainability. Although it has retained its original meaning as a measure of the solvency of government, it has acquired several dimensions in relation to governments that have no difficulty in meeting present obligations. Current sustainability analysis focuses on fiscal conditions that may retard economic growth, increase tax burdens or transfer significant costs to future taxpayers. These dimensions reflect concerns that governments accumulate long-term liabilities that do not appear in current budgets but may disadvantage future generations when they are due [Díaz, Izquierdo and Ugo, 2004: 6].

\subsection{Determinants of Budget Deficit Growth}

A model involving variation in inflation, government expenditure during wartime, cyclical fluctuation in output during economic boom and recession in the postwar period was tested if it differs significantly from those during the world wars in the Swiss federal state. The estimate showed some cyclical fluctuation in the world war periods. This supports the assertion that significant determinant of budget deficit is increase in state expenditure during wartime. In this case, civilian expenditure was reduced and/or taxes increased to finance military expenditure during the war [Gebhard and Silika, 2006: 18-21]. In Ghana, changes in inflation, interest rate and real GDP have reacted negatively to changes in budget deficit. For instance, high inflation in 1983 caused budget deficit to increase by 35.8 percent due to decline in direct tax revenue. Also, changes in real interest rate increased budget deficit by 11.3 percent of GDP in 1984. Again, high wage bill increased the deficit by 2.5 
percent in 1985. Thus, changes in macroeconomic variables have had strong impact on the fiscal deficit in Ghana. However, these effects have become less pronounced over the past years as the Ghanaian economy has grown more stable [Wetzel and Roumeen, 1991: 48].

\subsection{Effects of Budget Deficit Growth and Economic Sustainability}

Financing of budget deficit in Ghana have had diverse macroeconomic burden on the economy. Central bank financing for instance, have expanded the monetary base and money supply. According to Wetzel and Roumeen [1991: 48], it distorted the distinction between monetary and fiscal policies whereas the sale of domestic bond increased interest rate. This led to increase in the net domestic financing from 0.49 percent of GDP in 2004 to 4.15 percent in 2006. As a result, money supply (currency and deposits) increased from 6.84 percent in 2005 to 34.4 percent in 2006. However, domestic interest and bank rate reduced due to low demand for bonds [ISSER, 2007: 30, 60, 65]. Also, Ghana has accumulated large external debt and so borrow externally only on short term bases at high interest rate. This is because foreign financing raises the cost of servicing external debt. For this reason, Ghana's access to external borrowing prior to 1984 had been limited, ranging between -0.74 and 1.62 percent of GDP. In recent times however, debt levels have been falling. External debt fell from 72.5 percent in 2004 to 26.9 percent in 2006 with debt service to GDP reducing from 6.8 percent in 2004 to 6.0 percent in 2006 . [Wetzel and Roumeen, 1991: 48; ISSER, 2007: 50, 101].

\section{Methodology}

\subsection{Variables of the Study}

The main variables employed in the study include government revenue, government expenditure and real gross domestic product (GDP).

1) Government revenue includes all amounts of money or income received from sources outside the government entity. This includes taxes, loan repayments, direct income, interests and grants obtained locally and externally.

2) Government expenditure involves spending by government authorities on goods and services. This includes spending on road maintenance, health, administration and security. It also includes subsidies, grants and debt servicing.

3) Real gross domestic product is the measure of changes in physical output in an economy between different time periods by valuing all goods and services at the same constant price. Thus, it measures the value of final goods and services produced in a given year when valued at constant prices [Parkin and Bade, 2003].

These variables are relevant to the study because changes in government spending or revenue create changes in fiscal deficits. For instance, rapid increase in government expenditure coupled with shortfalls in tax revenue will persistently create budget deficit.

\subsection{Model Specification, Estimation and Tests}

This study adopts the present value budget constraint model used by Kustepeli and Onel [2004: 7-8] in specifying a model for budget deficit sustainability of Ghana. It is the most commonly used model in the study of budget deficit sustainability base on intertemporal budget constraint (IBC) of government [Gebhard and Silika, 2006: 5]. The model begins with government budget constraint expressed as follows:

$$
G_{t}+\left(1+r_{t}\right) \beta_{t-1}=R_{t}+\beta_{t}
$$

Where money finance $\left(M_{t}-M_{t-1}\right)$ is assumed to be negligible and t B is stock of government debt, $R_{t}$ is

government revenue $G_{t}$ is government expenditure excluding interest payments and $r_{t}$ is real interest rate. The expression shows that the public sector finances its fiscal deficit through borrowing. Hence, it indicates the sources and uses of public sector funds. It is therefore suitable for this study since Ghana finances its fiscal deficits mainly through borrowing [ISSER, 1994: 30].

Equation 1 is then solved recursively by including subsequent and infinite periods. This generates the present value budget constraint (PVBC) expressed as follows:

$$
\beta_{t-1}=\sum_{x=0}^{\infty}\left(\frac{1}{1+r_{t}}\right)^{x+1}\left(R_{t+x}-E_{t+x}\right)+\lim _{x \rightarrow \infty}\left(\frac{1}{1+r_{t}}\right)^{x+1} \beta_{t+x}
$$


Where $E_{t}=G_{t}+\left(r_{t}-r\right) \beta_{t-1}$, and the interest rate $r_{t}$ is assumed to be stationary around a mean, $r$. Theexpression means that the stock of government debt must be equal to the present value of primary budget surpluses with no issue of new debt to finance the deficit.

Yet, intertemporal sustainability requires that the no Ponzi game (NPG) condition holds.

Therefore, the PVBC is reduced to NPG condition represented in equation 3;

$$
\lim _{x \rightarrow \infty}\left(\frac{1}{1+r_{t}}\right)^{x+1} \beta_{t+x}=0
$$

This means that present discounted value of all future debt balances must sum up to zero because if lenders behave optimally and rationally, government must pay off its debt at some point in time. Thus, government cannot continue to roll over its debt perpetually into the future since lenders are rational.

In this study, we test the cointegration between government revenue $\left(R_{t}\right)$ and government expenditure $\left(G_{t}\right)$ in the following testable regression function:

$$
R_{t}=\alpha+\beta G_{t}+\mu_{t}
$$

Where $\alpha$ is a constant which shows the degree of drift in the parameters, $\mu_{t}$ is the error term whilst $\beta$, shows the extent to which changes in government expenditure affects the value of government revenue [Bajo-Rubio, Díaz-Roldán and Esteve, 2005: 2-4]

\subsection{Data Sources}

The study employed annual time series data on government revenue-GDP and government expenditure-GDP of Ghana for the period 1960 to 2010. The data was obtained from World Bank development indicators' CD-ROM and the state of the Ghanaian economy.

\subsection{Data Analysis}

In order to determine the causal link between government expenditure-GDP and revenue-GDP series of Ghana, we apply the Granger causality test as stated in the following expression below:

$$
\begin{gathered}
\ln E X G_{t}=\alpha_{0}+\sum_{i=1}^{n} a_{1 i} \ln E X G_{t-i}+\sum_{i=1}^{n} a_{2 i} \ln R E V G_{t-i}+\varepsilon_{1 t} \\
\ln R E V G_{t}=\beta_{0}+\sum_{k=1}^{m} \beta_{1 i} \ln R E V G_{t-k}+\sum_{k=1}^{m} \beta_{2 k} \ln R E V G_{t-k}+\varepsilon_{2 t}
\end{gathered}
$$

Where $\ln E X G_{t}$ and $\ln R E V G_{t}$ are $\log$ of government expenditure-GDP and log of government revenue-GDP at time t; $\alpha_{0}$ and $\beta_{0}$ are intercepts, $a_{1 i}$ and $\beta_{1 i}$ are slope coefficients of own lagged values, $a_{2 i}$ and $\beta_{2 k}$ are slope coefficients of lagged values of other variables in equation 5 and 6 respectively whilst $\varepsilon$ is error term. In estimating the causal link between government expenditure-GDP and revenue-GDP series of Ghana, the null hypothesis of no Granger causality is tested against the alternative of Granger causality. In this case, the null hypothesis is not rejected if $\sum a_{2 i}$ and $\sum \beta_{2 k}$ are statistically equal to zero simultaneously.

In applying the Engle-Granger test, the long run cointegration relation between government expenditure-GDP and government revenue-GDP series of Ghana is estimated by using OLS method. This is expressed in the following testable function:

$$
\ln E X G_{t}=\alpha+\beta \ln R E V G_{t}+\mu_{t}
$$

Where variables are as defined. In this case, the hypothesis to be tested in support of the objective of this study is stated as follows:

$H_{0}$ : Government revenue and expenditure are not cointegrated.

$H_{1}$ : Government revenue and expenditure are cointegrated. 
This result is possible if the series of residuals $\left(\mu_{t}\right)$ is stationary and displays no unit root. Hence, we apply the estimated cointegration relationship to generate residual errors. The estimated OLS residual errors are then tested for unit root. In respect of this, the following hypothesis is tested to find out the stationarity of the residuals:

$H_{0}: \varepsilon_{t} \quad$ is not stationary (no cointegration)

$H_{1}: \varepsilon_{t}$ is stationary (cointegration)

For the budget deficit of Ghana, the following hypothesis is tested to establish the statistical significance of the cointegrating vector:

$$
\begin{aligned}
& H_{0}: \beta=1 \\
& H_{1}: \beta \neq 1
\end{aligned}
$$

Also, the short-run relationship between government expenditure and revenue of Ghana is estimated by using error correction model (VECM). The model uses the first difference of the variables. For Ghana, the testable function is specified as follow:

$$
\Delta \ln E X G_{t}=\alpha+\beta \Delta \ln E X G_{t}(-1)+\delta \Delta \ln R E V G_{t}(-1)+\phi \Delta E C T(-1)+\varepsilon_{t}
$$

Where $\Delta$ is the first-order time difference, $\Delta \mathrm{ECT}$ is the first difference of the error correction term and $\alpha$ is the intercept. $\varepsilon_{t}$ is the error term with zero mean whilst $\delta$ is the coefficient of the period change in government revenue which tends to capture the short-term effects. Also, $\varphi$ is the coefficient of the error correction term which incorporates feedback in the relationship between government revenue and expenditure

For the budget deficit of Ghana, the study tests whether there is heteroscedasticity based on the following hypothesis:

$H_{0}$ : There is no heteroscedasticity.

$H_{1}$ : There is heteroscedasticity.

In the case of Ghana, the hypothesis test is conducted by employing the white heteroscedasticity test.

For efficiency of the estimates, the study also tests for autocorrelation since the classical linear regression model assumes the existence of no autocorrelation in the disturbance term. This is important because, in the absence of the assumption, the OLS estimator may no longer have minimum variance among all linear unbiased estimators. In this case, the estimates may not be as efficient as other linear unbiased estimators and that the t, $\mathrm{F}$ and $\chi^{2}$ tests may give misleading conclusions [Gujarati, 2004: 442].

In testing for autocorrelation, the following hypothesis is stated:

$H_{0}$ : There is no autocorrelation in the disturbance term.

$H_{1}$ : There is autocorrelation in the disturbance term.

\section{Empirical Results}

\subsection{Overview}

The most common practice, among the set of methods to evaluate budget deficit sustainability, is to investigate past fiscal data to establish if there is cointegration between government revenue and expenditure. For the economy of Ghana, we perform the econometric analysis by using the OLS estimator.

\subsection{Stationary and Unit Root Test}

Table 1 shows the results of the test statistics for both ADF and PP of government revenue-GDP and government expenditure-GDP series of Ghana in respect of the study period. The variables have been tested, with and without trend, in their log levels as per Panel A and first differences as per Panel B. Table 1 panel A indicates that the results of ADF and PP tests do not allow for rejection of the null hypothesis of non-stationarity for the $\log$ levels of government expenditure-GDP series (ln EXG) and government revenue-GDP series (ln REVG). This occurred both for the test with trend and the constant without trend.

In this case, the test show that both government expenditure-GDP series and revenue-GDP series of Ghana supports the null hypothesis when ADF and PP tests are used. This means that government expenditure and revenue of Ghana are non-stationary in their log levels. However, many time series data need to be appropriately 
differenced in order to achieve stationarity [Dolado, Jesús and Marmol, 1999: 3]. As a result, we proceed to test and confirm the stationarity of these variables after their first difference. The unit root test on the variables in their first difference produced estimates that show a reverse situation compared to the estimates in the log levels. Table 1 panel B shows the test for first differences of government expenditure-GDP series $(\triangle \ln E X G)$ and government revenue-GDP series $(\triangle \operatorname{lnREVG})$ of Ghana. From the estimation, both tests reject the null hypothesis of non-stationarity of the variables after first differencing. This is possible even at 1 percent level of significance for both ADF and PP tests with trend and without trend.This leaves no controversy in terms of both ADF and PP tests in achieving stationarity after first difference of government expenditure-GDP and government revenue-GDP series.

Table 1. Results of the unit root tests

Panel A:Log Levels

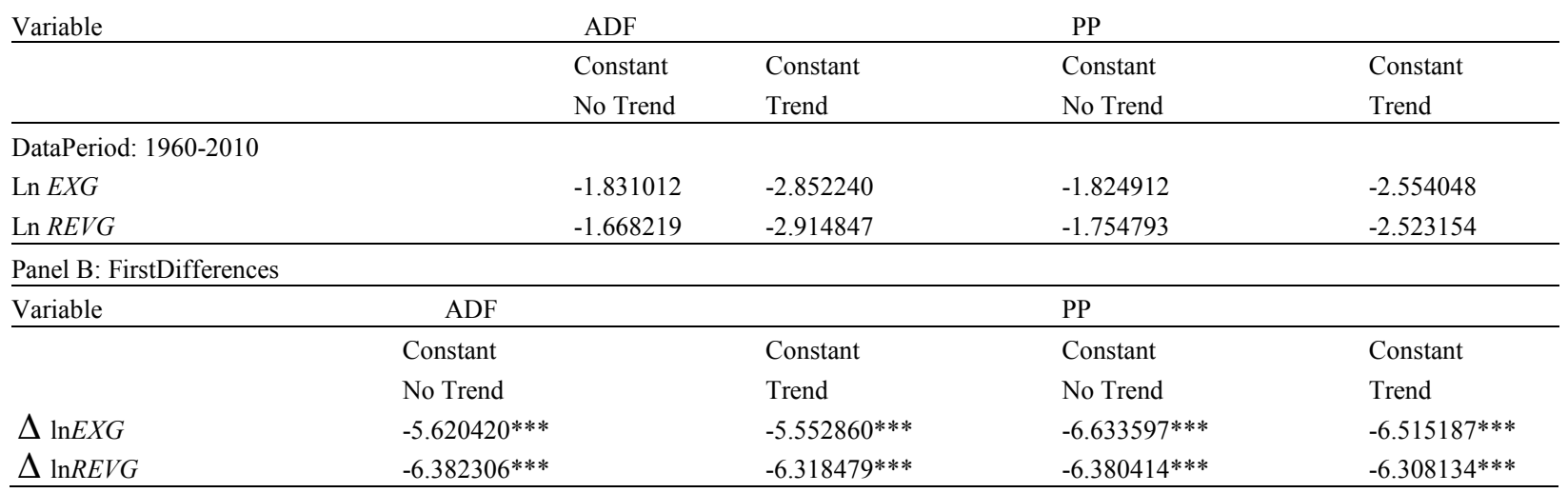

Note: $* * *$ indicatesrejection ofthe null hypothesisof non-stationaryat 1 percentsignificancelevel basedon theMacKinnon critical values.

In this case, the estimation show that government expenditure-GDP and revenue-GDP series favour the existence of unit root in the log levels, but indicate stationarity after first differencing. Hence, we conclude that both government expenditure and revenue of Ghana are stationary and integrated of order one. Yet, before estimating the cointegration relation between the variables, we proceed to find the causal link between these variables.

\subsection{Granger Causality Test}

The result of the Granger causality test is represented in table 2 .

Table 2. Granger causality test

\begin{tabular}{llll}
\hline Null Hypothesis: & Obs & F-Statistic & Probability \\
\hline $\ln E X G$ does not Granger Causeln $R E V G$ & 50 & 0.45684 & 0.50264 \\
$\ln R E V G$ does not Granger Causeln $E X G$ & 50 & 2.20932 & 0.14431 \\
\hline
\end{tabular}

The estimates from table 2 indicate that we reject the null hypothesis of no causality between government expenditure-GDP and revenue-GDP of Ghana in both cases. This means that the coefficients $\sum a_{2 i}$ and $\sum \beta_{2 k}$ are statistically not equal to zero. In this case, there is bi-directional causality such that both government expenditure and revenue of Ghana have temporal precedence over each other. Yet, the existence of Granger causality does not imply that the occurrence of revenue is the result of expenditure. It means that changes in revenue precede changes in expenditure.

\subsection{Cointegration Tests}

4.4.1 Long-Run Relationship between Government Expenditure and Revenue

The results from the estimation are presented in tables 3 and 4 . 
Table 3. Long run cointegration results using OLS method

Dependent Variable: LNEXG

\begin{tabular}{|c|c|c|c|c|}
\hline Variable & Coefficient & Std. Error & $\mathrm{t}$-Statistic & Prob. \\
\hline LNREVG & 0.991195 & 0.071018 & $13.95699^{* * *}$ & 0.0000 \\
\hline $\mathrm{C}$ & 0.271404 & 0.203966 & 1.330633 & 0.1899 \\
\hline \multicolumn{3}{|l|}{ R-squared } & \multicolumn{2}{|l|}{0.808968} \\
\hline \multicolumn{3}{|c|}{ Adjusted R-squared } & \multicolumn{2}{|l|}{0.804815} \\
\hline \multicolumn{3}{|c|}{ F-statistic } & \multicolumn{2}{|l|}{194.7976} \\
\hline \multicolumn{3}{|c|}{ Prob(F-statistic) } & \multicolumn{2}{|l|}{0.000000} \\
\hline \multicolumn{3}{|c|}{ Durbin-Watson stat } & \multicolumn{2}{|l|}{1.895125} \\
\hline
\end{tabular}

Table 4. Long run cointegration results using OLS method

Dependent Variable: LNREVG

\begin{tabular}{lllll}
\hline Variable & Coefficient & Std. Error & t-Statistic & Prob. \\
\hline LNEXG & 0.816155 & 0.058476 & $13.95699^{* * *}$ & 0.0000 \\
C & 0.322608 & 0.182514 & $1.767581^{*}$ & 0.0838 \\
R-squared & & 0.808968 & \\
Adjusted R-squared & & 0.804815 & \\
F-statistic & & 194.7976 & \\
Prob(F-statistic) & & 0.000000 & \\
Durbin-Watson stat & & & 1.885802 & \\
\hline
\end{tabular}

Note: $*$ and $* * *$ denote the rejection of the null hypothesis at 10 percent and 1 percent significance level respectively

The estimation of the long-run cointegration relationship between government expenditure-GDP and revenue-GDP series of Ghana shows that both variables are statistically significant at 1 percent level. In this case, both variables depend on each other. We therefore proceed to test the statistical significance of the cointegration coefficients.

In a second step to the Engle-Granger procedure, the estimated cointegration relationship between government revenue-GDP and expenditure-GDP series is used to generate residual errors. The generated residuals are then subject to the test for unit roots. Within this procedure, the error term represents the deviation of government expenditure and revenue from their long-run equilibrium relationship. Rejecting the null hypothesis of the presence of unit root in the residuals implies rejection of the null hypothesis of no cointegration. The test result is represented in table 5:

Table 5. Test for unit root in the residuals

\begin{tabular}{lllll}
\hline Panel A:Level & & & & \\
\hline Variable & ADF & & PP & Constant \\
& Constant & Constant & Constant & Trend \\
\hline No Trend & & Trend & & \\
\hline RESID & $-3.866473^{* * *}$ & $-3.884572^{* *}$ & $-3.866473 * * *$ & $-3.884572^{* *}$ \\
\hline
\end{tabular}

Notes: $* *$ and $* * *$ indicate rejection of the null hypothesis of non-stationary at 5 percent and 1 percent significance level respectively based on the MacKinnon critical values.

The estimations in table 5 show that the test for unit root in the residuals of Ghana's budget deficit fails to accept the null hypothesis at 5 percent significance level. Both the ADF and PP tests reject the null hypothesis at 5 percent significance level for stationarity of the residuals. It thus, assumes the presence of cointegration in the residuals of government revenue-GDP and expenditure-GDP series of Ghana when there is trend in the variables. On the other hand, when no trend in the variables is considered, ADF and PP tests reject the null hypothesis of no stationarity at 1 percent significance level. Therefore, it can Ghana's budget deficit is rejected at 5 percent 
significance level. This result is achieved after testing the residuals in their levels. With this firm result of stationarity and cointegration of the variables at their levels, it does not therefore call for further tests of the variables at their first difference. By this conclusion, it means that the budget deficit and hence government revenue and expenditure of Ghana are cointegrated.

Table 6. Results of the wald restriction test

\begin{tabular}{llll}
\hline Equation & Coefficient & Null Hypothesis & F-Statistics \\
\hline $\ln E X G=f(\ln R E V G)$ & 0.991195 & $H_{0}: \beta=1$ & $0.015373[0.9019]$ \\
$\ln R E V G=f(\ln E X G)$ & 0.816155 & $H_{0}: \beta=1$ & $9.884251[0.0029]$ \\
\hline
\end{tabular}

According to the results obtained, we fail to reject the null hypothesis at 10 percent significance level where government expenditure-GDP series depends on government revenue-GDP series $[\ln E X G=f(\ln R E V G)]$. It is therefore concluded that the coefficient of $\operatorname{lnREVG}(\beta=0.991195)$ is statistically not different from one at 10 percent level of significance. For this reason, Ghana's budget deficit is said to be sustainable in the strong sense. In this case, it means that the series of government expenditure and revenue move together in the long run and that the coefficient of government revenue is statistically equal to or not different from one.

However, when government revenue-GDP series is dependent on expenditure-GDP series $[\ln E X G=f(\ln E X G)]$, it rejects the null hypothesis and concludes that $\beta$ is statistically different from one. This indicates that the budget deficit of Ghana will explode over the long run. Hence, it is not possible for government to continue experiencing stable debt-to-GDP ratio indefinitely in the long run [Xiomara and Greenidge, 2003: 2-4]. For this reason, government cannot continue to service its debt which accumulates from budget deficit without large future correction to the balance of income and expenditure. Thus, the revenue capacity of government will not be able to support government expenditure in the long run. This may call for large fiscal adjustments.

From the preceding analysis, it shows that the study have satisfied both sufficient and necessary conditions and, therefore concludes that government expenditure-GDP series of Ghana depends on government revenue-GDP series for the period 1960 to 2010. It is therefore important to find out the extent of adjustment of disequilibrium between government expenditure-GDP series and government revenue-GDP series of Ghana within the study period.

\subsubsection{Estimation of the Short-Run Dynamic Model}

The vector error correction model (VECM) of Engle-Granger is then used to estimate the short-run dynamic relationship between government expenditure and revenue of Ghana.

The results of the short-run model of the relationship between government revenue-GDP and government expenditure-GDP is presented in Table 7.

Table 7. Estimation of short run dynamic model

Dependent Variable: $\triangle$ LNEXG

\begin{tabular}{lllll}
\hline Variable & Coefficient & Std. Error & t-Statistic & Prob. \\
\hline $\mathrm{C}$ & 0.018320 & 0.031116 & 0.588761 & 0.5592 \\
$\Delta L N$ EXG(-1) & 0.327530 & 0.211667 & 1.547384 & 0.0129 \\
$\Delta L N$ REVG(-1) & -0.274931 & 0.237208 & -1.159029 & 0.0253 \\
ECT(-1) & -0.526017 & 0.199678 & $-2.634327^{* *}$ & 0.0118 \\
R-squared & & & 0.747201 & \\
Adjusted R-squared & & 0.686287 & \\
F-statistic & & 2.416531 & \\
Prob (F-statistic) & & 0.007976 & \\
Durbin-Watson stat & & 1.949101 & \\
\hline
\end{tabular}

Note: ** denotes rejection of the null hypothesis at 5 percent significance level.

In the case of Ghana, the coefficient of the error correction term achieved the conventional negative sign. It is also statistically significant at 5 percent, which further confirms the long run cointegration relationship between 
the variables. This means that there exists a long-run cointegration relationship between government expenditure and revenue of Ghana. The implication is that in the long run when budget deficit, at any given time $t$, exceeds that of the previous period $(t-1)$ for which $E X G_{t-1}$ is greater than $R E V G_{t-1}$ because $\delta$ is less than zero, the error correction term works to push government expenditure back towards equilibrium. This long term stability however, does not rule out the possibility of Ghana running short-term budget deficits as argued by Carneiro et al [2005: 113-114].

Also, with an estimated coefficient of -0.53 , it indicates that approximately 53 percent of disequilibrium generated is restored every year following shocks to the system. In the case of Ghana therefore, the speed of adjustment parameter is relatively large with the right negative sign, indicating that there is a greater rate of convergence toward equilibrium. By this finding, it is concluded that any disequilibrium within the budget deficit of Ghana in the short run is quickly adjusted and converged back to equilibrium in the long run. Hence, the model combines flexibility in dynamic specification with desirable long-run properties.

\section{Discussion}

From the analysis, it shows that the OLS estimate is linear, unbiased and normally distributed. However, it is important to test for heteroscedasticity and autocorrelation since the estimate may no longer be efficient. In testing for heteroscedasticity, the estimate indicates that the number of observations multiplied by R-square (n. $\mathrm{R}^{2}$ ) gives a value of 1.539232 at a probability of 0.463191 .

For all practical purposes, the study does not reject the null hypothesis. It is therefore, concluded that there is no heteroscedasticity in government expenditure-GDP and revenue-GDP series of Ghana over the study period. This means that the assumption of equal variance of the disturbance term hold for government expenditure and revenue of Ghana between 1960 and 2010.

The test for autocorrelation, in respect of Ghana, produces a Durbin-Watson statistic of 1.895125. This means that the test for autocorrelation of Ghana's budget deficit fails to reject the null hypothesis of no autocorrelation. Thus, government expenditure and revenue exhibit no autocorrelation and hence the budget deficit of Ghana exhibits minimum variance in the disturbance term. This makes it efficient in arriving at better conclusions.

Based on the estimation and analysis, the long-run cointegration relationship of Ghana shows that government expenditure-GDP series is dependent on government revenue-GDP series for the period between 1960 and 2010. The estimate in this case produces a long-run cointegration coefficient for government revenue-GDP series $(\beta)$ of 0.991195. This indicates that the long-run coefficient of Ghana's budget is statistically significant at 1 percent level. The estimated value of $\beta$ being less than one means that anytime government revenue changes by 1 unit on the average, it leads to a corresponding change of 0.99 units in government expenditure of Ghana. By this finding, it indicates that the relationship is characterized by persistently higher government spending relative to revenues but spending and revenue share a long-run equilibrium relationship.

In addition, the estimate of the long-run cointegration relationship of Ghana's budget deficit indicates an $\mathrm{R}$-squared value of 0.808968 and adjusted R-squared of 0.804815 . This means that approximately 80 percent of the variations in government expenditure of Ghana are explained by variations in government revenue. The estimates have been obtained with F-statistic of 194.7976 at a probability of 0.0000 . This rejects the null hypothesis and confirms the long run cointegration relationship between government expenditure and revenue of Ghana between 1960 and 2010. This fulfills the intertemporal budget constraint of government which imposes restriction on the long run relationship between expenditure and revenue such that government runs some surpluses in the future to offset prevailing deficits. The restriction allows government to rule out Ponzi scheme where new issues of debt must necessarily be made to finance deficits. This gives government the ability to raise the necessary funds either by balancing its budget in present value terms or borrowing temporarily to be able to service its debt [Kustepeli and Onel, 2004: 2-3].

\section{Conclusion}

The study sought to evaluate the sustainability of budget deficit in Ghana between 1960 and 2010. The estimation uses operational budget deficit due to the inclusion of real interest payment in primary deficit. This is a good choice since interest payment ultimately limits the deficit finance through growth of accumulated debt. Sustainability analysis requires government to be able to service its debts without large future correction to the budget. This would avoid rolling over initial debts with the interest forever. The unit root tests favoured the stationarity of the variables at 1 percent significance level after first differencing. This means government expenditure and revenue are integrated of order one process. Also, a Granger causality test supported the existence of bi-directional causality between the variables. Hence, past and present values of government 
revenue provide important information to forecast future values of expenditure. The Engle-Granger cointegration test achieved a cointegration vector of 0.991195 at 1 percent level of significance indicating long run cointegration relationship between government expenditure and revenue. It shows that approximately 80 percent of variations in government expenditure of Ghana are explained by variations in government revenue. The linear restriction test showed that is statistically not different from $\beta$ one at 10 percent Significance level. This indicates sustainability of budget deficit in the strong sense. Also, the error correction model achieved the conventional negative sign at 5 percent significance level. This indicates that approximately 53 percent of disequilibrium is restored every year following shock to the system. This is relatively large indicating greater rate of convergence toward equilibrium. The diagnostic tests showed that government expenditure and revenue of Ghana exhibits no heteroscedasticity and autocorrelation. Also, a normality test based on Jarque-Bera supported the normality assumption. It is recommended that efforts should be made to consistently increase government revenue as revenue and expenditure must be stationary and integrated of the same order. Since reduction in government expenditure is not plausible, the tax net of Ghana should be expanded to capture all "taxable" individuals and firms. This would ensure that expenditure do not move too far away from revenue. Any policy to increase expenditure in Ghana should consider past and present values of government revenue. This is because expenditure and revenue take temporal precedence over each other.

\section{References}

Afonso, A., \& Rault, C. (2007). Should we Care for Structural Breaks When Assessing Fiscal Sustainability? Lisbon, Technical University of Lisbon. Retrieved from http://pascal.iseg.utl.pt/ depeco/wp/wp012008.pdf

Amir, K. (2005). Sustainability of the Fiscal Process in Developing Countries-Egypt, Iran and Turkey: A Multicointegration Approach. Ottawa, Carleton University. Retrieved from http://www.erf.org.eg/CMS/uploads/pdf/1184499958_Amir_Kia.pdf

Aráoz, M., Cerro, M., Meloni, O., \& Genta, S. (2006). Fiscal Sustainability and Crises - The Case of Argentina. UNSTA, University of Tucuman. Retrieved http://www.aaep.org.ar/anales/works/works2006/Araoz_Cerro_Meloni_SoriaGenta.pdf

Arestis, P., \& Sawyer, M. (2006). The Intertemporal Budget Constraint and the Sustainability of Budget Deficits. Leeds, University of Leeds. Retrieved from http://www.palgrave.com/products/title.aspx?pid=288001

Aristovnik, A., \& Bostjan, B. (2007). Fiscal Sustainability in Selected Transition Countries. MPRA Paper No. 122, Slovenia, University of Ljubljana. Retrieved from http://mpra.ub.uni-muenchen.de/122/1/MPRA_paper_122.pdf

Auerbach, J. A., \& Laurence, J. K. (1995). Macroeconomics: An Integrated Approach. Ohio, South-Western College Publishing.

Bajo-Rubio, O., Díaz-Roldán, C., \& Esteve, V. (2005). US Deficit Sustainability Revisited: A Multiple Structural Change Approach. University of Manchester, Instituto de Estudios Fiscales. Retrieved from http://www.ief.es/documentos/recursos/publicaciones/papeles_trabajo/2005_19.pdf

Bank of Ghana. (2005). The HIPC Initiative and External Debt: An Empirical Assessment and Policy Challenges. Accra, Bank of Ghana Research Department.

Bank of Ghana. (2007). Bank of Ghana Monetary Policy Report. Vol. 1, No. 6/2007. Accra, Bank of Ghana Research Department.

Barua, S. (2005). An Examination of Revenue and Expenditure Causality in Bangladesh: 1974-2004. World Bank Working Paper Series WP 0605 Dhaka, Bangladesh Bank Policy Analysis Unit (PAU). Retrieved from http://siteresources.worldbank.org/PSGLP/Resources/wp0605.pdf

Bebi, H. (2000). Sustainability of Budget Deficits-A Case Study of Namibia (1991-1999). Nepru Working Paper No. 73, Windhoek, Namibian Economic Policy Research Unit. Retrieved from http://openlibrary.org/books/OL3985876M/Sustainability_of_budget_deficits

Blanchard, O. J., \& Fischer, S. (1989). Lectures on Macroeconomics. Cambridge Massachusetts Institute of Technology, MIT Press.

Carneiro, F. G., Joao, F., \& Barry, B. (2005). Government Revenues and Expenditures in Guinea-Bissau: Causality and Cointegration. Journal of Economic Development, 30(1). Texas, World Bank. Retrieved from http://www.jed.or.kr/full-text/30-1/08_J680.PDF 
De Castro, F., \& Pablo Hernandez, D. C. (2002). On the Sustainability of the Spanish Public Budget Performance, Madrid-Spain, Instituto De Estudios Fiscales. Retrieved from http://www.ief.es/documentos/recursos/publicaciones/revistas/hac_pub/160_Castro.pdf

Delong, B. J. (2002). Macroeconomics (Rev. ed.). New York: McGraw-Hill Companies Inc.

Dholakia, R. H., \& Navendu, K. (2005). Consistent Measurement of Fiscal Deficit and Debt of States in India. Economic and Political Weekly, 38(10). India. Retrieved from http://www.iimahd.ernet.in/publications/data/2004-07-05rdholakia.pdf

Díaz, A. C., Alejandro, I., \& Panizza, U. (2004). Fiscal Sustainability in Emerging Market Countries with an Application to Ecuador, Washington, D.C., 20577, Inter-American Development Bank. http://www.iadb.org/res/publications/pubfiles/pubWP-511.pdf

Dinh, H. T. (1999). Fiscal Solvency and Sustainability in Economic Management. Southern Africa Region, the World Bank. Retrieved from http://www-wds.worldbank.org/servlet/WDSContentServer/WDSP/IB/1999/11/19/000094946_9911050543 2935/Rendered/PDF/multi_page.pdf\%20Download\%20Restriction:\%20no

Dolado, J. J., Gonzalo, J., \& Francesc, M. (1999). Cointegration. Madrid, University of Carlos.

Easterly, W., \& Klaus, S. H. (1993). Fiscal Deficits and Macroeconomic Performance in Developing Countries. The World Bank Research Observer, Washington DC, World Bank. Retrieved from http://www-wds.worldbank.org/external/default/WDSContentServer/WDSP/IB/1999/09/23/000178830_98 101911471889/Rendered/INDEX/multi_page.txt

Fischer, S., \& William, E. (1990). The Economics of the Government Budget. The World Bank Research Observer, 2(5), Oxford, Oxford University Press. Retrieved from: http://www1.worldbank.org/publicsector/pe/PEAMMarch2005/easterly.pdf

Gebhard, K., \& Silika, P. (2006). Sustainability of Swiss Fiscal Policy. CESIFO Working Paper 1689(1), Switzerland, University of St. Gallen. Retrieved from http://www.cesifo-group.de/portal/page/portal/DocBase_Content/WP/WP-CESifo_Working_Papers/wp-ces ifo-2006/wp-cesifo-2006-03/cesifo1_wp1689.pdf

Government of Ghana. (2005). Ghana-Enhanced Structural Adjustment Facility. Economic and Financial Policy Framework Paper, 1998-2000. Accra, Ministry of Finance.

Gujarati, D. N. (2004). Basic Econometrics (4th ed.). New York: McGraw-Hill Companies.

Holmes, J. M., Otero, J., \& Theodore, P. (2007). Are EU Budget Deficits Sustainable? New Zealand, Waikato University. Retrieved from http://www.rcfea.org/RePEc/pdf/wp17_09.pdf

Institute of Economic Affairs. (2008). Annual 2007 Economic Review and Outlook. Accra, Institute of Economic Affairs.

Institute of Statistical, Social and Economic Research. (1994). The State of the Ghanaian Economy in 1993. Accra-Legon, Wilco Publicity Services Ltd.

Institute of Statistical, Social and Economic Research. (2007). The State of the Ghanaian Economy in 2006. Accra-Legon, Wilco Publicity Services Ltd.

International Monetary Fund. (2001). Ghana - Enhanced Heavily Indebted Poor Countries (HIPC) Initiative Preliminary Document, Washington DC, International Monetary Fund, International Development Association

International Monetary Fund. (2002). Assessing Sustainability, Washington DC, International Monetary Fund, International Development Association.

Issahaku, A. N. (1999). The Political Economy of Economic Reform in Ghana: Implications for Sustainable Development. Washington, World Employment Programme Research. Retrieved from http://www.jsd-africa.com/Jsda/Spring\%202000/articles/Reform\%20in\%20Ghana.pdf

Jacobs, D., Nicholaas, S., \& Jan, H. (2002). Alternative Definitions of the Budget Deficit and its Impact on the Sustainability of Fiscal Policy in South Africa, Pretoria, University of Pretoria. http://dx.doi.org/10.1111/j.1813-6982.2002.tb01303.x

Kustepeli, Y., \& Gulcan, O. (2004). Fiscal Deficit Sustainability with a Structural Break: An Application to Turkey. İzmir-Turkey, Dokuz Eylül University. Retrieved from: 
http://www.docstoc.com/docs/68100677/FISCAL-DEFICIT-SUSTAINABILITY-WITH-A-STRUCTURA L-BREAK-AN

Luporini, V. (1999). Sustainability of the Brazilian Fiscal Policy and Central Bank Independence. Cedeplar Belo Horizonte, the Federal University of Minas Gerais. Retrieved from http://www.cedeplar.ufmg.br/pesquisas/td/TD\%20125.pdf

Mahendra, R. (2006). Assessing Sustainability of Fiji's Public Debt: A Cointegration Analysis Approach. Fiji, Reserve Bank of Fiji. Retrieved from http://www.reservebank.gov.fj/docs/Spch\%20by\%20Dr\%20Mahendra\%20Reddy $\% 20$ at $\% 20$ Eco\%20Assoc $\% 20$ Forum\%20RBF_01mar06.pdf

Mankiw, G. N. (2003). Macroeconomics (5th ed.). New York: Worth Publishers Inc.

Moalusi, D. K. (2004). Causal Link between Government Spending and Revenue: A Case Study of Botswana. Botswana, Fordham University. $\quad$ Retrieved http://www.fordham.edu/images/Undergraduate/economics/DKMFORD1.pdf

Mokoena, T. M. (2005). Testing for fiscal sustainability in South Africa. Pretoria: University of Pretoria.

Mutasa, C. (2008). The Challenges of Debt Sustainability in Africa: The Case of Ghana, Accra, S.K.B Asante International Consultancy $\quad$ Services. $\quad$ Retrieved http://www.afrodad.org/site/Publications/Debt\%20Sustainability/dsa\%20ghana\%20final.pdf

Nyamongo, M., Moses, S., \& Niek, S. (2007). Government Revenue and Expenditure Nexus in South Afric. South African Journal of Economic and Management, 10(2). Retrieved from http://repository.up.ac.za/bitstream/handle/2263/3282/Nyamongo_Government\%282007\%29.pdf?sequence $=1$

Organisation for Economic Co-Operation and Development. (2005). Sustainable Budget Policy - Concepts and Approaches, Thailand, Allen Schick Brookings Institute.

Oshikoya, T., \& Tarawalie, A. B. (2008). Sustainability of Fiscal Policy: The West African Monetary Zone (WAMZ) Experience. Journal of Monetary and Economic Integration, 9(2). Lagos, ECOWAS. Retrieved from http://www.wami-imao.org/ecomac/english/newreports/v11_no1/pdfdocs/v9n2_unit1.pdf

Pomeyie, P. (2001). Macroeconomics: An Introductory Textbook. Accra, Wade Laurel co.

Quintos, C. E. (1995). Sustainability of the Deficit Process with Structural Shifts. Journal of Business and Economic Statistics, 13(4). Washington, American Statistical Association. Retrieved from http://wenku.baidu.com/view/610c4f07cc175527072208f0.html

Raghbendra, J. (2001). Macroeconomics of Fiscal Policy in Developing Countries. Australia, Australian National University. Retrieved from http://www.wider.unu.edu/stc/repec/pdfs/dp2001/dp2001-71.pdf

Straub, R., \& Ivan, T. (2007). Assessing the Impact of a Change in the Composition of Public Spending. IMF Working Paper, Washington DC, International Monetary Fund. Retrieved from http://www.ecb.int/pub/pdf/scpwps/ecbwp795.

Wetzel, D. L., \& Roumeen, I. (1991). The Macroeconomics of Public Sector Deficits: The Case of Ghana. Washington DC, World Bank. from http://www-wds.worldbank.org/servlet/WDSContentServer/WDSP/IB/1991/05/01/000009265_3961001075 213/Rendered/PDF/multi_page.pdf

Xiomara, A., \& Greenidge, K. (2003). Debt and Fiscal Sustainability in Barbados. Bridgetown, Central Bank of Barbados. Retrieved from http://centralbank.org.bb/webcbb.nsf/WorkingPapers/BA33B2A964946094042578090048D705/\$FILE/WP 2002pp11_30.pdf 